UDC 332

\title{
ANALYSIS ON CONTRACT TERMINATION OF GOVERNMENT PROJECTS ON CONSTRUCTION WORK
}

\author{
Hasan Muhamad, Student \\ Master's Program in Civil Engineering, University of Brawijaya, Indonesia \\ Anwar M. Ruslin, Suryo Eko Andi \\ Civil Engineering Department, University of Brawijaya, Indonesia \\ *E-mail: hasankarisma@gmail.com
}

\begin{abstract}
Construction is one of the efforts to meet human needs. Construction work may be government projects and private projects - both are different. Government projects must be in accordance with the regulations at each stage, starting project announcement to bidding. The contractor winning the bids will undertake the initial stages of project development until the project is completed. However, in fact, some projects also failed project and the government terminates contracts, as in Lumajang Regency from 2014 to 2015. Contractors whose contract has been terminated will be included in the black list by LPSE. Many factors lead to contract termination. Previous studies mention factors like materials, finance, equipment, contractor performance, owner performance, managerial factors as well as external factors and situation as the cause of contact termination. This study will analyze the dominant factors leading to contract termination in Lumajang as well as the strategy to overcome the problem. The methods used are correlation analysis, Importance Performance Analysis, and SWOT analysis.
\end{abstract}

\section{KEY WORDS}

Contractor, factors causing contract termination, correlation analysis, Importance performance analysis, SWOT analysis.

A government construction project will definitely start with the bidding process. The auction process organized by the Government uses the Layanan Pengadaan Secara Elektronik (LPSE) or the Electronic Procurement Service system. Lumajang regency uses the complete LPSE system by 2014. The LPSE system itself aims to increase efficiency, effectiveness, quality, and transparency in the procurement of goods and services. In addition, this system aims to minimize face-to-face contact between bidders and project owners. Through the LPSE system, the government provides explanations to bidders. This stage is called as aanwyzing or an online explanation of the articles in the Work Plan and Terms (RPS), the illustration of the tender, and the Budget Plan (RAB).

In the implementation of construction work, some contractors do not optimally use the aanwijzing stage and this is one of the causes of contract termination due to contractors ignoring terms of a project. In addition, at the time of submission of administrative documents, many contractors provide inappropriate data or simply borrow documents from other contractors, such as a Skill Letter (SKA). In terms of administrative requirement, SKA is important as it guarantees one's expertise; the inability to present one SKA is also the cause of contract termination later. During the 2014 to 2015, there have been many government projects terminate.

The study aims to find out the factors causing contract termination as to minimize such case in the future.

The objectives of the study are as follows:

- to know the dominant factors causing contract termination in government projects; 
- to know strategies to minimize contract termination in government projects under the perspective of consumer satisfaction.

The focus or limitation of the study is as follows:

- developments of buildings and roads in Lumajang Regency;

- development of buildings and construction work in 2014 and 2015, which is the development of: the development of Regional Disaster Management Agency office; the development of neighborhood roads in Bedayu Talang Village and Kandang Tepus Village in 2015 by the Public Work Service; the rehabilitation of the office of the Department of Culture and Tourism in 2015; the development of neighborhood roads (between Randuagung and Ranulogong) in Randuagung Village and the development of neighborhood roads in Tunung Village in 2015; and the development of the office of Department of Cooperatives of Small and Medium Enterprises.

\section{LITERATURE REVIEW}

Construction contract is a contract in the implementation of building construction, both implemented by the government and private parties (Salim H.S., 2003). According to Article 1 Paragraph (5) of the Construction Services Law, construction contract refers to all documents governing the legal relationship between service users and service providers in the implementation of construction works.

Here is the stage of contract auction and post-qualification direct election with a knockout system: announcement; registration and retrieval of Procurement Documents; explanation; the submission of the Bidding Document; opening of Bidding Document; bid evaluation: evaluation of qualifications; verification of qualifications; the production of Minutes of auction results; determination of the winner; announcement of the winner; refutation; and refutation of appeal (if required).

According to Praboyo (1999), the factors causing a project delay are labor, material, equipment, situation, and managerial.

\section{METHODS OF RESEARCH}

Framework. Contract termination is a failure in construction work. Before the termination, the project is not in accordance with the schedule, resulting delays. The study aims to examine factors affecting contract termination and the strategies to overcame termination in the future. The research framework is presented in Figure 1 below:

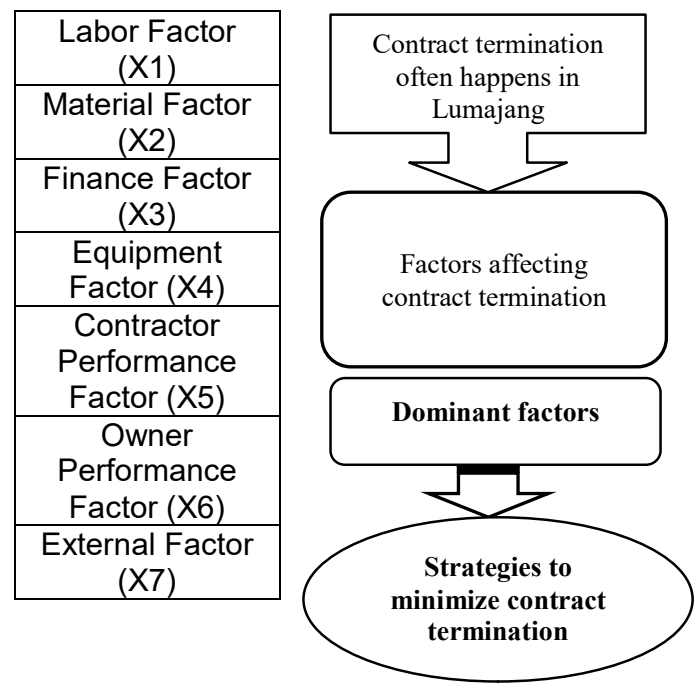

Figure 1 - Research Framework 
Data Collection. Data was collected using 35 questionnaires distributed to respondents and through interviews. Data collection was done directly to respondents to avoid mistakes in understanding the statement and with the hope that respondents could provide useful inputs to the study. Respondents were given open questions so they could explain the reasons for the answer.

There were two sources of data, namely primary and secondary data sources. The primary data were obtained from respondents through questionnaires and direct interviews about indicators determining participation of small-scale contractors in auctions. The respondent was a contractor company represented by the director or staff handling the auction process at each of the represented companies. The secondary data was obtained from literature studies with various books, electronic books, and electronic journals in and outside the country.

Table 1 - Research Variables

\begin{tabular}{|c|c|}
\hline Variable & Indicators \\
\hline Labor $\left(\mathrm{x}_{1}\right)$ & $\begin{array}{l}\text { Slow labor } \mathrm{X}_{1,1} \\
\text { Lack of experts } \mathrm{X}_{1,2} \\
\text { Labor productivity } \mathrm{X}_{1,3} \\
\text { Labor availability } \mathrm{X}_{1,4} \\
\text { Labor absence } \mathrm{X}_{1,5} \\
\text { Strike } \mathrm{X}_{1,6} \\
\text { Labor motivation } \mathrm{X}_{1,7}\end{array}$ \\
\hline Material $\left(\mathrm{x}_{2}\right)$ & $\begin{array}{l}\text { Lack of materials } X_{2,1} \\
\text { Low material quality } X_{2,2} \\
\text { Delay in material delivery } X_{2,3} \\
\text { Price raise } X_{2,4} \\
\text { Inaccurate time for material order } X_{2,5} \\
\text { Unreliable supplier } X_{2,6}\end{array}$ \\
\hline Equipment $\left(\mathrm{x}_{3}\right)$ & $\begin{array}{l}\text { Lack of equipment } X_{3,1} \\
\text { Equipment damage } X_{3,2} \\
\text { Bad quality of equipment } X_{3,3} \\
\text { Delay in equipment provision } X_{3,4} \\
\text { Problem in equipment placement } X_{3,5} \\
\text { Modern equipment availability } X_{3,6} \\
\end{array}$ \\
\hline Finance $\left(\mathrm{x}_{4}\right)$ & $\begin{array}{l}\text { High importance } X_{4,1} \\
\text { Financial problems by contractors } X_{4,2} \\
\text { Financial problems by the owner } X_{4,3} \\
\text { Delay in payment by the owner without clear reasons } X_{4,4} \\
\text { Delay in payment to suppliers and sub-contractors } X_{4,5} \\
\text { Problems in monthly payment } X_{4,6}\end{array}$ \\
\hline Contractor Performance $\left(x_{5}\right)$ & $\begin{array}{l}\text { Inappropriate construction method } X_{5,1} \\
\text { Inaccurate time estimation } X_{5,2} \\
\text { Inaccurate finance prediction } X_{5,3} \\
\text { Not optimal location management and supervision } X_{5,4} \\
\text { Incompetent project teams } X_{5,5} \\
\text { Incompetent sub-contractors } X_{5,6} \\
\text { Not optimal use of technology } X_{5,7} \\
\text { Less attention to contract documents } X_{6,8}\end{array}$ \\
\hline Owner Performance $\left(x_{6}\right)$ & $\begin{array}{l}\text { Slow decision-making } X_{6,1} \\
\text { Experience in construction work } X_{6,2} \\
\text { Design changes } X_{6,3} \\
\text { Less visit by the owner representative } X_{6,4} \\
\text { Less coordination and communication with sub-contractors } X_{6,5} \\
\text { Feasibility study on the construction site } X_{6,6} \\
\text { Unsuitable auction stages } X_{6,7} \\
\text { No mastery in procurement procedures } X_{6,8}\end{array}$ \\
\hline External Factors $\left(x_{7}\right)$ & $\begin{array}{l}\text { Unpredictable in field situations } X_{7,1} \\
\text { Fluctuation of dollar value against rupiah } X_{7,2} \\
\text { Delay in site checking } X_{7,3} \\
\text { Problems with the surrounding community } X_{7,4} \\
\text { Weather } X_{7,5} \\
\text { Conflict, war, and community disputes } X_{7,6}\end{array}$ \\
\hline
\end{tabular}




\section{RESULTS AND DISCUSSION}

General Conditions. The study took place in Lumajang covering five big government projects experiencing contract termination in 2014 and 2015. Based on the interview results, contract termination happens because lack of materials, the high price of materials, inaccurate time estimation, unstable construction sites, slow decision-making by owners, and lack of management of the project teams.

Descriptive Analysis. The analysis is intended to describe the characteristics of respondents. Respondents in this study came from Lumajang consisted of official employees in charge of projects on construction works ranging from KDP, PPTK, and supervisors as well as contractors such as directors, deputy directors, site managers, and site engineers. Respondents were drawn from five major projects experienced contract termination in Lumajang. Of the 35 questionnaires distributed, all of them were returned and 30 questionnaires were confirmed as qualified for the data analysis.

Validity and Reliability Test:

Validity Test. Validity test is done to know the extent to which a research instrument can measure variables. A validity test is intended whether the questionnaire item is in accordance with the variable to be measured. Testing the validity of each item on the questionnaire helps us to know whether the question item is valid or not. A validity test is done by comparing the corrected item-total correlation of each statement with the total score obtained. If the corrected item-total correlation is greater than r-table, then the question item is valid. Using the distribution ( $r$ table) for $\alpha$ at 0.05 and the number of respondents for 30 , the $r$-table is 0,361 , by using the following equation formula:

$$
r_{\text {count }}=\frac{\mathrm{n}\left(\sum \mathrm{xiyi}\right)-\left(\sum \mathrm{xi}\right) \cdot\left(\sum \mathrm{yi}\right)}{\sqrt{\left(n \cdot \sum x i^{2}-\left(\sum x i^{2}\right) \cdot\left(n \cdot \sum y i^{2}-\left(\sum y i\right)^{2}\right)\right.}}
$$

Table 2 - Validity Test Results

\begin{tabular}{|c|c|c|c|c|}
\hline Variable Code & R-table & $\begin{array}{c}\mathrm{R} \text { count } \\
\text { Satisfaction }(\mathrm{X})\end{array}$ & $\begin{array}{c}\mathrm{R} \text { count } \\
\text { Importance }(\mathrm{Y})\end{array}$ & Note \\
\hline \multicolumn{5}{|c|}{ Labor } \\
\hline $\mathrm{X}_{1.1}$ & 0.361 & 0.510 & 0.484 & Valid \\
\hline $\mathrm{X}_{1.2}$ & 0.361 & 0.543 & 0.444 & Valid \\
\hline $\mathrm{X}_{1.3}$ & 0.361 & 0.385 & 0.361 & Valid \\
\hline $\mathrm{X}_{1.4}$ & 0.361 & 0.370 & 0.392 & Valid \\
\hline $\mathrm{X}_{1.5}$ & 0.361 & 0.405 & 0.408 & Valid \\
\hline $\mathrm{X}_{1.6}$ & 0.361 & 0.382 & 0.369 & Valid \\
\hline $\mathrm{X}_{1.7}$ & 0.361 & 0.628 & 0.594 & Valid \\
\hline \multicolumn{5}{|c|}{ Material } \\
\hline $\mathrm{X}_{2.1}$ & 0.361 & 0.412 & 0.387 & Valid \\
\hline $\mathrm{X}_{2.2}$ & 0.361 & 0.529 & 0.384 & Valid \\
\hline $\mathrm{X}_{2.3}$ & 0.361 & 0.385 & 0.402 & Valid \\
\hline $\mathrm{X}_{2.4}$ & 0.361 & 0.380 & 0.375 & Valid \\
\hline $\mathrm{X}_{2.5}$ & 0.361 & 0.515 & 0.373 & Valid \\
\hline $\mathrm{X}_{2.6}$ & 0.361 & 0.624 & 0.452 & Valid \\
\hline \multicolumn{5}{|c|}{ Equipment } \\
\hline $\mathrm{X}_{3.1}$ & 0.361 & 0.690 & 0.364 & Valid \\
\hline$X_{3.2}$ & 0.361 & 0.668 & 0.439 & Valid \\
\hline$X_{3.3}$ & 0.361 & 0.792 & 0.423 & Valid \\
\hline$X_{3.4}$ & 0.361 & 0.625 & 0.365 & Valid \\
\hline$X_{3.5}$ & 0.361 & 0.555 & 0.371 & Valid \\
\hline $\mathrm{X}_{3.6}$ & 0.361 & 0.380 & 0.454 & Valid \\
\hline \multicolumn{5}{|c|}{ Finance } \\
\hline $\mathrm{X}_{4.1}$ & 0.361 & 0.478 & 0.418 & Valid \\
\hline$X_{4.2}$ & 0.361 & 0.501 & 0.541 & Valid \\
\hline$X_{4.3}$ & 0.361 & 0.543 & 0.683 & Valid \\
\hline$X_{4.4}$ & 0.361 & 0.603 & 0.625 & Valid \\
\hline $\mathrm{X}_{4.5}$ & 0.361 & 0.782 & 0.703 & Valid \\
\hline$X_{4.6}$ & 0.361 & 0.701 & 0.705 & Valid \\
\hline
\end{tabular}


Eurasia: Economics \& Business, 7(13), July 2018

DOI https://doi.org/10.18551/econeurasia.2018-07

\begin{tabular}{|l|l|l|l|l|}
\hline \multicolumn{5}{|c|}{ Contractor Performance } \\
\hline$X_{5.1}$ & 0.361 & 0.603 & 0.444 & Valid \\
$X_{5.2}$ & 0.361 & 0.450 & 0.706 & Valid \\
$X_{5.3}$ & 0.361 & 0.469 & 0.776 & Valid \\
$X_{5.4}$ & 0.361 & 0.661 & 0.508 & Valid \\
$X_{5.5}$ & 0.361 & 0.588 & 0.453 & Valid \\
$X_{5.6}$ & 0.361 & 0.526 & 0.454 & Valid \\
$X_{5.7}$ & 0.361 & 0.592 & 0.739 & Valid \\
$X_{6.8}$ & 0.569 & 0.365 & Valid \\
\hline$X_{6.1}$ & 0.361 & Owner Performance & Valid \\
$X_{6.2}$ & 0.361 & 0.369 & 0.468 & Valid \\
$X_{6.3}$ & 0.361 & 0.365 & 0.431 & Valid \\
$X_{6.4}$ & 0.361 & 0.486 & 0.470 & Valid \\
$X_{6.5}$ & 0.361 & 0.445 & 0.437 & Valid \\
$X_{6.6}$ & 0.361 & 0.476 & 0.481 & Valid \\
$X_{6.7}$ & 0.361 & 0.688 & 0.786 & 0.495 \\
$X_{6.8}$ & 0.361 & 0.602 & 0.444 & Valid \\
\hline$X_{7.1}$ & 0.489 & & Valid \\
$X_{7.2}$ & 0.361 & External Factors & Valid \\
$X_{7.3}$ & 0.361 & 0.691 & 0.525 & Valid \\
$X_{7.4}$ & 0.361 & 0.693 & 0.762 & Valid \\
$X_{7.5}$ & 0.361 & 0.733 & 0.646 & Valid \\
$X_{7.6}$ & 0.361 & 0.794 & 0.664 & Valid \\
\hline
\end{tabular}

Table 2 shows that the correlation between each indicator to the total score of each variable is valid because $(R)$ count $>(R)$ table, so it can be concluded that all indicators are valid and can be used in the next stage.

Table 3 - Reliability Test Results

\begin{tabular}{|c|c|c|c|}
\hline $\begin{array}{c}\text { Variable } \\
\text { Code }\end{array}$ & $\begin{array}{l}\text { Cronbach Alpha } \\
\text { Importance }\end{array}$ & $\begin{array}{c}\text { Cronbach Alpha } \\
\text { Satisfaction }\end{array}$ & Note \\
\hline \multicolumn{4}{|c|}{ Labor } \\
\hline $\mathrm{X}_{1.1}$ & 0.725 & 0.743 & Reliable \\
\hline $\mathrm{X}_{1.2}$ & 0.727 & 0.744 & Reliable \\
\hline$X_{1.3}$ & 0.727 & 0.745 & Reliable \\
\hline $\mathrm{X}_{1.4}$ & 0.727 & 0.745 & Reliable \\
\hline $\mathrm{X}_{1.5}$ & 0.727 & 0.745 & Reliable \\
\hline $\mathrm{X}_{1.6}$ & 0.725 & 0.744 & Reliable \\
\hline$X_{1.7}$ & 0.724 & 0.744 & Reliable \\
\hline \multicolumn{4}{|c|}{ Material } \\
\hline $\mathrm{X}_{2.1}$ & 0.727 & 0.744 & Reliable \\
\hline $\mathrm{X}_{2.2}$ & 0.727 & 0.744 & Reliable \\
\hline $\mathrm{X}_{2.3}$ & 0.728 & 0.746 & Reliable \\
\hline $\mathrm{X}_{2.4}$ & 0.727 & 0.745 & Reliable \\
\hline $\mathrm{X}_{2.5}$ & 0.727 & 0.744 & Reliable \\
\hline $\mathrm{X}_{2.6}$ & 0.725 & 0.741 & Reliable \\
\hline \multicolumn{4}{|c|}{ Equipment } \\
\hline$X_{3.1}$ & 0.728 & 0.742 & Reliable \\
\hline$X_{3.2}$ & 0.726 & 0.743 & Reliable \\
\hline$X_{3.3}$ & 0.727 & 0.741 & Reliable \\
\hline$X_{3.4}$ & 0.726 & 0.742 & Reliable \\
\hline$X_{3.5}$ & 0.728 & 0.744 & Reliable \\
\hline$X_{3.6}$ & 0.726 & 0.745 & Reliable \\
\hline \multicolumn{4}{|c|}{ Finance } \\
\hline $\mathrm{X}_{4.1}$ & 0.726 & 0.744 & Reliable \\
\hline $\mathrm{X}_{4.2}$ & 0.724 & 0.743 & Reliable \\
\hline $\mathrm{X}_{4.3}$ & 0.720 & 0.742 & Reliable \\
\hline $\mathrm{X}_{4.4}$ & 0.721 & 0.741 & Reliable \\
\hline $\mathrm{X}_{4.5}$ & 0.721 & 0.740 & Reliable \\
\hline $\mathrm{X}_{4.6}$ & 0.721 & 0.741 & Reliable \\
\hline
\end{tabular}


Eurasia: Economics \& Business, 7(13), July 2018

DOI https://doi.org/10.18551/econeurasia.2018-07

\begin{tabular}{|c|c|c|c|}
\hline \multicolumn{4}{|c|}{ Contractor Performance } \\
\hline$X_{5.1}$ & 0.718 & 0.742 & Reliable \\
\hline$X_{5.2}$ & 0.722 & 0.744 & Reliable \\
\hline$X_{5.3}$ & 0.722 & 0.743 & Reliable \\
\hline$X_{5.4}$ & 0.725 & 0.741 & Reliable \\
\hline$X_{5.5}$ & 0.727 & 0.743 & Reliable \\
\hline$X_{5.6}$ & 0.725 & 0.742 & Reliable \\
\hline$X_{5.7}$ & 0.722 & 0.742 & Reliable \\
\hline$X_{6.8}$ & 0.728 & 0.742 & Reliable \\
\hline \multicolumn{4}{|c|}{ Owner Performance } \\
\hline $\mathrm{X}_{6.1}$ & 0.726 & 0.745 & Reliable \\
\hline$X_{6.2}$ & 0.727 & 0.745 & Reliable \\
\hline $\mathrm{X}_{6.3}$ & 0.726 & 0.743 & Reliable \\
\hline$X_{6.4}$ & 0.726 & 0.743 & Reliable \\
\hline$X_{6.5}$ & 0.726 & 0.743 & Reliable \\
\hline $\mathrm{X}_{6.6}$ & 0.723 & 0.742 & Reliable \\
\hline$X_{6.7}$ & 0.726 & 0.741 & Reliable \\
\hline $\mathrm{X}_{6.8}$ & 0.726 & 0.744 & Reliable \\
\hline \multicolumn{4}{|c|}{ External Factors } \\
\hline $\mathrm{X}_{7.1}$ & 0.725 & 0.742 & Reliable \\
\hline$X_{7.2}$ & 0.727 & 0.742 & Reliable \\
\hline$X_{7.3}$ & 0.723 & 0.741 & Reliable \\
\hline$X_{7.4}$ & 0.723 & 0.741 & Reliable \\
\hline$X_{7.5}$ & 0.724 & 0.742 & Reliable \\
\hline$X_{7.6}$ & 0.726 & 0.740 & Reliable \\
\hline
\end{tabular}

Correlation Analysis. The independent variable $(Y)$ is contract termination and the dependent variables are $x_{1}, x_{2}, x_{3}, x_{4}, x_{5}, x_{6}, x_{7}$. The framework is presented as follows:

\begin{tabular}{|l|}
\hline Labor Factor $\left(\mathrm{X}_{1}\right)$ \\
\hline Material Factor $\left(\mathrm{X}_{2}\right)$ \\
\hline Finance Factor $\left(\mathrm{X}_{3}\right)$ \\
\hline Equipment Factor $\left(\mathrm{X}_{4}\right)$ \\
\hline Contractor Performance $\left(\mathrm{X}_{5}\right)$ \\
\hline Owner Performance $\left(\mathrm{X}_{6}\right)$ \\
\hline External Factor $\left(\mathrm{X}_{7}\right)$ \\
\hline
\end{tabular}

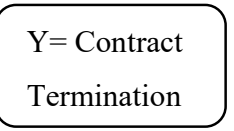

Figure 2 - The Relationship between the Dependent and Independent Variable

The correlation analysis of this study aims to determine how strong or related the independent variable to the dependent variables. In other words, the correlation analysis will show the most influential variable leading to contract termination.

Table 4 - Interpretation of Correlation Coefficients

\begin{tabular}{|c|c|}
\hline Coefficient Interval & Description \\
\hline $0.000-0.199$ & Very low correlation \\
\hline $0.200-0.399$ & Low correlation \\
\hline $0.400-0.599$ & Medium correlation \\
\hline $0.600-0.7999$ & Strong correlation \\
\hline $0.800-1.000$ & Very strong correlation \\
\hline
\end{tabular}

From the results of analysis using SPSS, the most dominant and the least dominant variable leading to contract termination have been confirmed based on perceptions of users. The list of each variable is presented in Table 5.

Table 6 shows that external factors are ranked first in the cause of contract termination with a correlation value of -0.394 and the second factor is equipment with a correlation value of -0.355 . It is followed by owner performance with a correlation value of -0.290 , contractor performance with a correlation value of -0.248 , material with a correlation value of -0.207 , financial factor with a correlation value of 0.039 , and labor with a correlation value of -0.010 . 
Eurasia: Economics \& Business, 7(13), July 2018

DOI https://doi.org/10.18551/econeurasia.2018-07

Table 5 - Correlations of the independent variable to contract termination

\begin{tabular}{|c|c|c|c|c|c|c|c|c|}
\hline \multicolumn{8}{|c|}{ Correlations of the independent variable to contract 3termination } \\
\hline & $\mathrm{x} 1$ & $\mathrm{x} 2$ & $\mathrm{x} 3$ & $\mathrm{x} 4$ & $\mathrm{x} 5$ & $\mathrm{x} 6$ & $\mathrm{x} 7$ & $\mathrm{Y}$ \\
\hline$\left(\mathrm{X}_{1}\right)$ & 1 & .492 & .417 & .593 & .446 & .396 & .710 &,- 010 \\
\hline$\left(\mathrm{X}_{2}\right)$ & .492 & 1 & .484 & .538 & .411 & .648 & .567 &,- 207 \\
\hline$\left(\mathrm{X}_{3}\right)$ & .417 & .484 & 1 & .427 & .367 & .465 & .341 &, 039 \\
\hline$\left(\mathrm{X}_{4}\right)$ & .593 & .538 & .427 & 1 & .634 & .696 & .784 &,- 355 \\
\hline$\left(\mathrm{X}_{5}\right)$ & .446 & .411 & .367 & .634 & 1 & .389 & .587 &,- 248 \\
\hline$\left(\mathrm{X}_{6}\right)$ & .396 & .648 & .465 & .696 & .389 & 1 & .508 &,- 290 \\
\hline$\left(\mathrm{X}_{7}\right)$ & .710 & .567 & .341 & .784 & .587 & .508 & 1 &,- 394 \\
\hline $\mathrm{Y}$ & -.010 & -.207 & .039 & -.355 & -.248 & -.290 & -.394 & 1 \\
\hline
\end{tabular}

Table 6 - Recapitulation of the Most Dominant Variables

\begin{tabular}{|c|c|c|c|}
\hline \multicolumn{3}{|c|}{$\begin{array}{c}\text { The Independent Variable to Dependent variables } \\
\text { Y= Factors Causing Contract Termination }\end{array}$} \\
\hline \multirow{2}{*}{ No } & Sub-variables & Rank & $\begin{array}{c}\text { Correlation } \\
\text { sig 0.01 and } 0.05\end{array}$ \\
\hline \multirow{2}{*}{1} & $\left(\mathrm{X}_{1}\right)$ & 7 & -.010 \\
2 & $\left(\mathrm{X}_{2}\right)$ & -.207 \\
3 & $\left(\mathrm{X}_{3}\right)$ & 5 & 039 \\
4 & $\left(\mathrm{X}_{4}\right)$ & 6 & -.355 \\
\cline { 2 - 2 } 5 & $\left(\mathrm{X}_{5}\right)$ & 2 & -.248 \\
6 & $\left(\mathrm{X}_{6}\right)$ & 4 & -.290 \\
7 & $\left(\mathrm{X}_{7}\right)$ & 3 & $-.394^{*}$ \\
\cline { 2 - 4 } & & 1 & \\
\hline
\end{tabular}

IPA analysis. Here is the explanation on respondents' answers on variables that have been give weight on the questionnaire. The data was processed with IPA to know which variables becoming a priority based on users.

Table 7 - The Level of Conformity of Each Variable and Total Suitability Level

\begin{tabular}{|c|c|c|c|c|}
\hline No & Indicator or Variable & $\mathrm{Xi}$ & $\mathrm{Yi}$ & Conformity level (\%) \\
\hline \multicolumn{5}{|c|}{ Labor (X1) } \\
\hline 1 & Motivation $\mathrm{X}_{1,7}$ & 96 & 108 & 88.88 \\
\hline 2 & Availability $\mathrm{X}_{1,4}$ & 80 & 130 & 61.53 \\
\hline 3 & Productivity $\mathrm{X}_{1,3}$ & 74 & 118 & 62.71 \\
\hline \multicolumn{5}{|c|}{ Material (X2) } \\
\hline 4 & Price raise $\mathrm{X}_{2,4}$ & 73 & 126 & 57.93 \\
\hline 5 & Inaccurate order time $X_{2,5}$ & 75 & 115 & 65.21 \\
\hline 6 & Unreliable suppliers $X_{2,6}$ & 68 & 115 & 56.52 \\
\hline \multicolumn{5}{|c|}{ Equipment (X3) } \\
\hline 7 & Damaqe $X_{32}$ & 75 & 119 & 63.02 \\
\hline 8 & Lack of equipment $X_{3,1}$ & 78 & 120 & 65 \\
\hline 9 & Problem in equipment placement $X_{3,5}$ & 85 & 117 & 72.64 \\
\hline \multicolumn{5}{|c|}{ Finance (X4) } \\
\hline 10 & Financial problems by the owner $\mathrm{X}_{4,3}$ & 92 & 117 & 78.63 \\
\hline 11 & Delay in payment without clear reasons $X_{4,4}$ & 87 & 111 & 78.37 \\
\hline 12 & Problems in monthly payment $\mathrm{X}_{4,6}$ & 88 & 111 & 79.27 \\
\hline \multicolumn{5}{|c|}{ Contractor Performance (X5) } \\
\hline 13 & Not optimal use of technology $X_{5,7}$ & 88 & 122 & 72.13 \\
\hline 14 & Incompetent sub-contractors $\mathrm{X}_{5,6}$ & 78 & 120 & 65 \\
\hline 15 & Inaccurate finance prediction $X_{5,3}$ & 88 & 117 & 75.21 \\
\hline \multicolumn{5}{|c|}{ Owner Performance (X6) } \\
\hline 16 & Feasibility study on construction sites $\mathrm{X}_{6,6}$ & 96 & 123 & 78.04 \\
\hline 17 & Less communication and coordination with contractors $X_{6,5}$ & 80 & 128 & 62.5 \\
\hline 18 & Inappropriate auction stage $X_{6,7}$ & 99 & 129 & 76.74 \\
\hline \multicolumn{5}{|c|}{ External Factors $(\mathrm{X} 7)$} \\
\hline 19 & Problems with the surrounding community $\mathrm{X}_{7,4}$ & 92 & 119 & 77.31 \\
\hline 20 & Unpredictable conditions of the construction sites $X_{7,1}$ & 87 & 117 & 74.35 \\
\hline 21 & Delay in location supervision $\mathrm{X}_{7,1}$ & 88 & 116 & 75.86 \\
\hline & TOTAL & 1767 & 2498 & 70.73 \\
\hline
\end{tabular}


The table of the variable conformity level and the total conformity level indicates a total level value of $70.73 \%$ and based on the assessment criteria, it has been confirmed that the level of service is still not satisfactory.

IPA (Importance Performance Analysis) Matrices. Based on the calculation, the average value of user satisfaction and importance of contractor, owner and supervisor is presented in the following table.

Table 8 - The Average Value of Importance and Satisfactory

\begin{tabular}{|c|c|c|c|}
\hline No & Indicator or Variable & $\mathrm{Xi}$ & $\mathrm{Yi}$ \\
\hline \multicolumn{4}{|c|}{ Labor (X1) } \\
\hline 1 & Motivation $\mathrm{X}_{1.7}$ & 2.46 & 3.93 \\
\hline 2 & Availability $\mathrm{X}_{1.4}$ & 2.66 & 4.33 \\
\hline 3 & Productivity $\mathrm{X}_{1.3}$ & 3.2 & 3.6 \\
\hline \multicolumn{4}{|c|}{ Material (X2) } \\
\hline 4 & Price raise $\mathrm{X}_{2.4}$ & 2.43 & 4.2 \\
\hline 5 & Inaccurate order time $X_{2.5}$ & 2.5 & 3.83 \\
\hline 6 & Unreliable suppliers $\mathrm{X}_{2.6}$ & 2.26 & 3.83 \\
\hline \multicolumn{4}{|c|}{ Equipment (X3) } \\
\hline 7 & Damage $\mathrm{X}_{3.2}$ & 2.6 & 4 \\
\hline 8 & Lack of equipment $X_{3.1}$ & 2.5 & 3.96 \\
\hline 9 & Problem in equipment placement $X_{3.5}$ & 2.83 & 3.9 \\
\hline \multicolumn{4}{|c|}{ Finance $(\mathrm{X} 4)$} \\
\hline 10 & Financial problems by the owner $\mathrm{X}_{4.3}$ & 3.06 & 3.9 \\
\hline 11 & Delay in payment without clear reasons $X_{4.4}$ & 2.9 & 3.7 \\
\hline 12 & Problems in monthly payment $\mathrm{X}_{4.6}$ & 2.93 & 3.7 \\
\hline \multicolumn{4}{|c|}{ Contractor Performance (X5) } \\
\hline 13 & Not optimal use of technology $X_{5.7}$ & 2.93 & 4.06 \\
\hline 14 & Incompetent sub-contractors $\mathrm{X}_{5.6}$ & 2.6 & 4 \\
\hline 15 & Inaccurate finance prediction $X_{5.3}$ & 2.93 & 3.9 \\
\hline \multicolumn{4}{|c|}{ Owner Performance (X6) } \\
\hline 16 & Feasibility study on construction sites $\mathrm{X}_{6.6}$ & 3.2 & 4.1 \\
\hline 17 & Less communication and coordination with contractors $X_{6.5}$ & 2.66 & 4.26 \\
\hline 18 & Inappropriate auction stage $\mathrm{X}_{6.7}$ & 3.3 & 4.3 \\
\hline \multicolumn{4}{|c|}{ External Factors (X7) } \\
\hline 19 & Problems with the surrounding community $X_{7.4}$ & 3.06 & 3.96 \\
\hline 20 & Unpredictable conditions of the construction sites $X_{7.1}$ & 2.9 & 3.9 \\
\hline 21 & Delay in location supervision $X_{7.1}$ & 2.93 & 3.86 \\
\hline \multicolumn{2}{|r|}{ Average } & 2.80 & 3.96 \\
\hline
\end{tabular}

Furthermore, the table above also describes the level of the satisfaction and the importance of the contractors and owner by plotting the respective mean values on Cartesian diagram, in which the $X$ axis is the level of satisfaction and the $Y$ axis is the importance level with the intersection point of the axis $(x, y)$. Data obtained from the calculation of the axis is that $x=2.80$ and $y=3.96$. The data is described as follows:

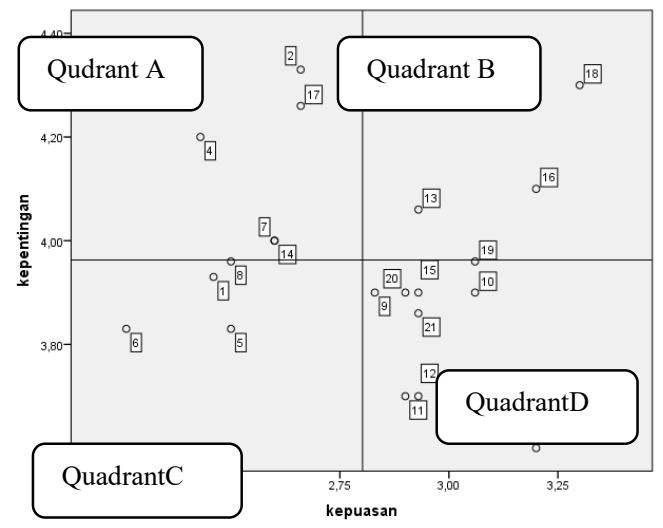

Figure 3 - The Cartesian Diagram of the of Satisfaction and the Importance of the Contractors and the Owner 
Table 9 - SWOT Analysis

\begin{tabular}{|c|c|}
\hline QUADRANT A & QUADRANT B \\
\hline $\begin{array}{l}\text { The indicators in this quadrant are not satisfactory } \\
\text { with a high degree of importance. Therefore, these } \\
\text { indicators should be given top priority to be } \\
\text { improved. }\end{array}$ & $\begin{array}{l}\text { The indicators in this quadrant have met } \\
\text { expectations and need to be maintained. In other } \\
\text { words, the indicators in this quadrant are said to } \\
\text { be satisfactory. }\end{array}$ \\
\hline $\begin{array}{l}\{2\} \text { Labor availability } X_{1,4} \\
\{4\} \text { Price raise in construction materials } X_{2,4} \\
\{7\} \text { Damage to equipment } X_{3,2} \\
\text { \{17\} Less communication and coordination with } \\
\text { contractors } X_{6,5} \\
\{14\} \text { Incompetent sub-contractors } X_{5,6}\end{array}$ & $\begin{array}{l}\{18\} \text { Inappropriate auction stage through LPSE } \\
X_{6,7} \\
\{13\} \text { Not optimal use of technology } X_{5,7} \\
\{16\} \text { Feasibility study on construction sites } X_{6,6} \\
\{19\} \text { Problems with the surrounding community } \\
X_{7,4}\end{array}$ \\
\hline QUADRANT C & QUADRANT D \\
\hline 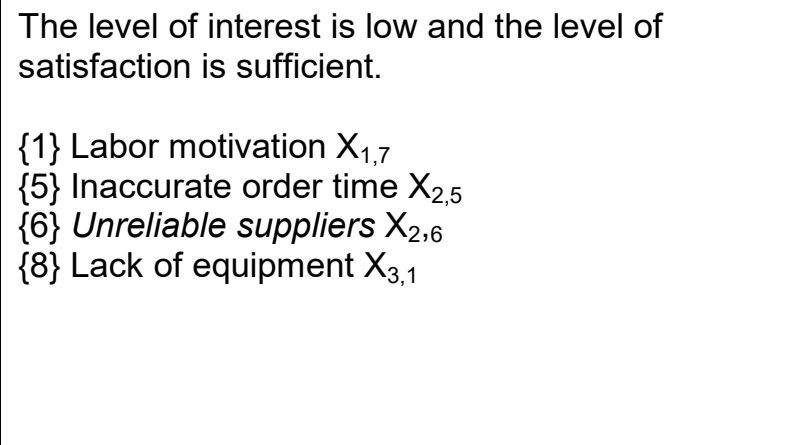 & $\begin{array}{l}\text { The indicator is considered less important but the } \\
\text { community is satisfied with its existence. } \\
\{3\} \text { Labor productivity } X_{1,3} \\
\{2\} \text { Delay in payment without clear reasons } X_{4,4} \\
\{12\} \text { Problems in monthly payment } X_{4,6} \\
\{10\} \text { Financial problems by the owner } X_{4,3} \\
\{15\} \text { Inaccurate finance prediction } X_{5,3} \\
\{21\} \text { Delay in location supervision } X_{7,3} \\
\{20\} \text { Unpredictable conditions of the construction } \\
\text { sites } X_{7,1} \\
\{19\} \text { Problem in equipment placement } X_{7,4}\end{array}$ \\
\hline
\end{tabular}

SWOT Analysis. A SWOT analysis is one of the methods used to describe the condition and evaluate a project based on internal factors and external factors; it stands for Strength, Weakness, Opportunities, and Threats. The SWOT analysis is expected to answerwhat strategies are used in order to minimize the contract termination on a project. The explanation is as follows.

Strengths:

- Inappropriate auction stage through LPSE $X_{6,7}$;

- Not optimal use of technology $X_{5,7}$;

- Feasibility study on construction sites $X_{6,6}$;

- Problems with the surrounding community $X_{7,4}$. Weaknesses:

- Labor availability $\mathrm{X}_{1,4}$;

- Price raise in construction materials $X_{2,4}$;

- Damage to equipment $\mathrm{X}_{3,2}$;

- Less communication and coordination with contractors $X_{6,5}$;

- Incompetent sub-contractors $X_{5,6}$. Opportunities:

- Abundant materials around the construction sites;

- Many contractors in Lumajang;

- Affordable wages of builders.

Threats:

- Less assertive regulation of sand material;

- Low material quality;

- Working performance less than the maximum;

- Low owner performance about mc.0;

- No black list for the supervisory consultant. Strategies (Strength and Opportunities):

- Improve the ability of LPSE auction stages; 
- Improve the quality of feasibility studies;

- Weekly payments to workers.

Strategies WO (Weaknesses and Opportunities):

- Improve labor management;

- Control the material price by the local government-owned enterprises;

- Improve the periodic maintenance of equipment;

- Well planning;

- Increase owner-contractor coordination. Strategies ST (Strengths and Threats):

- Consultation with the Ministry of Energy and Natural Resources related to sand management;

- Review the location before signing the project mutual agreement;

- Provide more training to the staff before the auction process;

- Adding working group personnel.

Strategies WT (Weaknesses and Threats)

- More reserve fund for contractors;

- Maintain good relationships between supervisors and contractors;

- Adjusted plans to the project site zone;

- Increase internal supervisory capacity.

\section{CONCLUSION}

Based on the results of research and discussion, it can be concluded in general that by using the correlation method, the external factor are influential to contract termination in construction work in Lumajang.

The external factors have a significant effect on the causes of contract termination in construction work in Lumajang. The external factorsare the most dominant variable to cause contract termination. The factors include problems with the surrounding community $\left(\mathrm{X}_{7,4}\right)$, unpredictable conditions of the construction sites $\left(X_{7,1}\right)$, and delay in location supervision $\left(\mathrm{X}_{7,1}\right)$.

From the method of correlation analysis followed by IPA method, it has been confirmed the most important and very satisfactory factors based on the perception of users. IPA shows variables that affect the level of user satisfaction and performance, where conditions have met expectations and need to be maintained; in other words, this variable is said to be satisfactory. The satisfactory variables are inappropriate auction stage through LPSE $\left(\mathrm{X}_{6,7}\right)$, not optimal use of technology $\left(X_{5,7}\right)$, feasibility study on construction sites $\left(X_{6,6}\right)$, and problems with the surrounding community $\left(\mathrm{X}_{7,4}\right)$.

Strategies on Strengths and Opportunities:

- Improve the ability of LPSE auction stages;

- Improve the quality of feasibility studies;

- Weekly payments to workers;

Strategies on Weaknesses and Opportunities:

- Improve labor management;

- Control the material price by the local government-owned enterprises;

- Improve the periodic maintenance of equipment;

- Well planning;

- Increase owner-contractor coordination.

Strategies on Strengths and Threats:

- Consultation with the Ministry of Energy and Natural Resources related to sand management;

- Review the location before signing the project mutual agreement;

- Provide more training to the staff before the auction process;

- Adding working group personnel. 
Strategies on Weaknesses and Threats:

- More reserve fund for contractors;

- Maintain good relationships between supervisors and contractors;

- Adjusted plans to the project site zone;

- Increase internal supervisory capacity.

Based on the findings and conclusions, here are the recommendations for the related parties:

- Owners are expected to improve their knowledge of LPSE auction stages, to improve the quality of feasibility studies, to improve internal supervisory capacity, and to add personnel to working groups.

- Contractors are expected to improve labor management, to improve equipment maintenance on a regular basis, and to make funding appropriate to field conditions.

- The government is expected to play an active role in supporting the smoothness and by establishing the local government-owned enterprises managing sand and other materials so development in Lumajang can run even better.

- Further research can focus on objects, for example bridges, roads, or buildings.

\section{REFERENCES}

1. Anom, I. G. N. (2015).Addendum Kontrak Pemborongan Perspektif Hukum Perjanjian di Indonesia. Jurnal Advokasi, 5(2): 183-198

2. Lpjk. (2011). Tentang Tata Cara Regristasi Ulang, Perpanjangan Masa Berlaku, Dan Permohonan Baru Sertifikat badan Usaha Jasa Pelaksana Konstruksi. Jakarta. Lembaga Pengembangan Jasa Konstruksi Nasional.

3. Ismael, I. (2013). Keterlambatan Proyek Konstruksi Gedung Faktor Penyebab Dan Tindakan Pencegahannya. Jurnal Momentum, 14(1): 46-56,

4. Narbuko, C., \& Ahmadi, H, A. (2003). Metodologi Penelitian, Jakarta: Penerbit PT Bumi Aksara.

5. Nazarkhan, Y. (2006). Mengenal kontrak konstruksi di Indonesia. Jakarta: Penerbit Gramedia.

6. Proboyo, B. (1999). Keterlambatan Waktu Pelaksanaan Proyek: Klassifikasi dan Peringkat dari Penyebab-Penyebabnya. Dimensi Teknik Sipil, 1(1), 49-58.

7. Keputusan Presiden Nomor 4 Tahun 2015Tentang Perubahan Keempat Atas Peraturan Presiden Nomor 54 Tahun 2010 Tentang Pengadaan Barang/Jasa Pemerintah. Lembaran Negara RI Tahun 2015, No. 5. Sekretariat Negara. Jakarta.

8. Sarwono, H., Ariono, A., Susan, S., Parasman, S., Weddy, B. S. (2007). Persyaratan Kontrak Untuk Pelaksnaan Konstruksi. Jakarta: Lembaga Pengembangan Jasa Konstruksi Nasional (LPJKN).

9. Triistiami, A. (2005). Cara Lebih Mudah Membaca Peraturan Pengadaan Barang dan Jasa Pemerintah. Jakarta. Primaprint. 